\title{
Indigenous Technological Knowledge in Pest and Disease Management of Agricultural Crops - A Review
}

\author{
Sarodee Boruah ${ }^{1 *}$, Sanjoy Borthakur ${ }^{1}$ and M. Neog $^{2}$ \\ ${ }^{1}$ Krishi Vigyan Kendra, Tinsukia, India \\ ${ }^{2}$ Directorate of Extension Education, Assam Agricultural University, Jorhat, Assam, India \\ *Corresponding author
}

\begin{abstract}
A B S T R A C T
Keywords

Indigenous technological knowledge (ITK),

Pest and disease management, India

Article Info

Accepted:

20 August 2020

Available Online:

10 September 2020

Pesticidal residues due to excessive or spurious use of chemicals become one of the curses of modern agriculture. This detrimental effect of chemicals brings the urgent need of ecofriendly and health hazard free sustainable agriculture. Indigenous technological knowledge (ITK) can play an important role in organic agriculture more particularly in pest and disease management of agricultural crops. The ITKs are eco-friendly and even compatible to other management practices, contributing towards pesticidal residue-free agricultural products. The North eastern states of India are heartland of indigenous groups of people and treasure house of ITKs applicable in agricultural sector. Due to rapid urbanization, the indigenous groups are losing concentration in conservation of these long earned ITKs which brings the importance of collection, documentation and scientific validation of ITKs. Therefore, a sincere attempt has been made to document some of the ITKs followed by the farmers and farm women of different parts of India for management of pests and diseases of agricultural crops.
\end{abstract}

\section{Introduction}

In agriculture, chemical pesticides are largely being used to control different pests and diseases of crops since 1800 with the introduction of arsenical insecticides and Bordeaux mixture fungicide. Now, there is overwhelming evidence that some of the pesticides do pose a potential risk to human and other life forms and unwanted side effects to the environment. No segment of the population is completely protected against exposure to pesticides. The world-wide deaths and chronic diseases due to pesticide poisoning is about 1 (one) million per year (Environews Forum, 1999) (Boruah, 2012). These detrimental effects of chemical pesticides bring the urgent need of organic agriculture. Therefore, it is important to develop holistic methods of managing pests and diseases of agricultural crops to make it more eco-friendly, economically viable and socially acceptable for the farmers (Dutta et al., 2015). In recent years, the importance of organic agriculture has been recognized and emphasized in those areas especially which are rich in biodiversity such as north eastern region of India. North eastern region of India 
is heartland of indigenous groups of people and since hundreds of years many indigenous groups have been living in this part maintaining their originalities in every sphere of life. In Assam, tribal people survive on local knowledge base (Kalita et al., 2010).

Indigenous knowledge is the knowledge of the indigenous people inhabiting different geographical regions of the world with their own language, culture, tradition, belief, folklore, rites and rituals. It refers to the unique, traditional, local knowledge existing within and developed around the specific conditions of women and men indigenous to a particular geographic area (Grenier, 1998).

In Agriculture, farmers from different diversity of the region have developed their own systems in cultivation of various crops. These practices are commonly known as indigenous technological knowledge (ITK) (Deka et al., 2006). ITKs are practical in nature and optimize local thinking in the field of agriculture, fisheries, health, livestock and forestry (Charyulu, 2007). Agricultural scientists believed that ITKs can play a significant role in solving issues related to modern agriculture and environment (Berkes et al., 2000). The scientific community accepted that the assessment of ITKs is an indispensable part of the introduction of new agricultural technology. It is recognized that the knowledge of farmers must be taken into account before any new technology is developed and disseminated.

Our ancestors have developed various agricultural practices for sustainable agriculture, most of them have scientific base. With times it has been noticed that due to rapid urbanization, the indigenous groups are losing concentration in conserving long earned indigenous technological knowledge (ITK) which they are carrying from generation to generation. For example, most of the rice farmers from Assam, on the day of first transplanting, used to plant a banana (Musa sp.) sucker, a black colocasia \{Colocasia esculentum (L.) Schott\} plant, wild turmeric (Curcuma angustifolia) and a bamboo perch in the north east corner of the field that is ready for transplanting. It is believed that these may help in pest control. But with times this practice has been lost in many regions of the state (Hazarika et al., 2009). Very few systematic works have been done in recent times in bringing the indigenous knowledge on important aspects of agriculture such as plant health management, soil health management etc. That is why here comes the importance of collection, documentation and scientific validation of ITKs to make them acceptable and applicable. Now a day even a new concept of 'Paramparagat Krishi' is also coming up. Govt of India has also emphasizing in this aspect by launching projects like 'Paramparagat Krishi Vikas Yojana (PKVY)'.

The Paramparagat Krishi Vikas Yojana (PKVY), launched in 2015 with the aim of supporting and promoting organic farming, in turn resulting in improvement of soil health and also reducing cost of cultivation for enhancing farmer's income. In the Paramparagat krishi, indigenous technological knowledge can be applied in every aspects of farming such as pest and disease management, weed management, soil health management and nutrient management etc. Thus, the documentation, validation and promotion of ITKs should form the basis for implementing natural resource conservation technologies.

Considering these facts, some of the important ITKs practised by the farmers and farm women of different parts of India India have been documented in this article. 
Role of ITKs in pest and disease management in traditional agriculture

Application of ITK in pest and disease management of different crops has been practised since long time. The ITKs are ecofriendly and compatible to other management practices also. Since chemical pesticides do pose serious threat to the soil, environment, plant, animal and human health, scientists are constantly working on alternative methods of pest and disease control in agriculture. Few attempts have been made by different scientists to document ITKs followed by farmers of different localities for management of pest and diseases of crops. Some of these are discussed below.

ITKs followed by indigenous people of India to manage insect pests and diseases of agricultural crops

\section{ITKs in insect pest management in field crops}

Deep ploughing in summer is helpful in preventing soil burrowing nematodes, white grubs, etc. (Shakrawar et al., 2018). This indigenous technology is prevalent in tribal areas of Madhya Pradesh.

Burning of waste material in field to produce heat. The heat which is produced by burning of waste material sterilizes the soil and kills the harmful microbes and controls damping off in nursery. It is practiced in late kharif and summer (Shakrawar et al., 2018).

For insect control, spraying of diluted onion or garlic juice is used by tribes of Chhindwara district of Madhya Pradesh to control grasshopper and other leaf inhabiting insects on Maize crop (Shakrawar et al., 2018).

Spraying neem solution to control all type of insects in crop. The solution of neem leaf extract and water ratio is of 1:6 (Shakrawar et al., 2018).

$5 \mathrm{~kg}$ cow dung, 5 litre of cow urine, $150 \mathrm{gm}$ of lime are mixed with 100 litres of water and then kept for one month for fermentation. After fermentation it can be sprayed to control aphids, bacterial and viral diseases of vegetable crops (Shakrawar et al., 2018).

Kerosene oil mixed water is poured in kharif season standing crop field especially in paddy field, and plants are thrilled by a long rope synchronously. All the insects like hoppers fell down in that water and die (Shakrawar et al., 2018).

Innovative trap for Rat control in paddy field: Farmers of many villages of Khowai district of Tripura such as Ganki, Sonatala, Chebri, Gourangatila, Batapura etc. use an innovative rat control method to minimize the yield loss due to rat attack especially in kharif and boro paddy. The innovative trap is a bow like structure made by the use of bamboo, iron wire and jute rope where one end act as a spring and other end to trap the rat when they will come to eat the bait (Patel, 2013). In the bait, they use rice, bread etc. as feed. The average per unit cost of such innovation is about Rs. 10-15 which is much less than the mechanical iron made commercial rat control trap (Patel, 2013).

Eraction of Germani bon (Chromolaena odorata) branches to control rice hispa and case worm. Leaf and stem act as repellent as they produce smell intolerable to the pests (Hazarika et al., 2009).

Pulling of kerosenized rope over the standing paddy crop to control stem borer, rice hispa and case worm. Stem borer lays eggs on the tip of the rice leaves. If we pull the kerosenized rope over the crop than the eggs of stem borer may damaged. And even the kerosene act as 
a toxicant to the pests. Furthermore because of oil film on the water surface, case worms cannot respire within the case (Hazarika et al., 2009).

Hanging of dead frog, crab (Carcinides sp.), jack fruit (Artocarpus heterophyllus) or Outenga (Dilenia indica) to control Gandhi bug in paddy. These items act as attractant for the pest as well as for the predators of the pest such as tiger beetle (Hazarika et al., 2009).

Eraction of bamboo perches for management of rice pests. Bamboo perches act as a perching for predaceous birds (Hazarika et al., 2009). Now this ITK has been included in the Bio Intensive Pest Management (BIPM) package of rice (AAU, Jorhat).

Application of Pomelo (Robab tenga) (Citrus grandis Osberk) peel to control rice hispa. The volatile compounds like limonene, $\alpha$-terpinene and $\alpha$ - pinene of Pomelo act as repellent of rice hispa (Hazarika et al., 2009).

Leaf clipping of rice seedlings to control stem borer attack as because by clippling we can remove egg masses of stem borer (Hazarika et al., 2009).

Broadcasting of rice husk $(5-10 \mathrm{~kg})$ or wood ash $(8 \mathrm{~kg})$ per acre mixed with 3-5 litre of kerosene during early morning to control rice stem borer. It acts as a chemical as well as physical poison (Hazarika et al., 2009).

Burning of rice stubbles after harvesting. Burning causes destruction of eggs and pests due to which pest infestation in next crop season become less (Saha and Dutta, 2013).

Hanging damaged audio visual tapes across the rice field during ripening stage to repel birds. The noise produced due to flapping of polythene scared birds feeding rice grains (Hazarika et al., 2009).

Broadcasting of goat's excreta at tillering stage to control rice hispa. Due to disagreeable odour pest fly away from the field (Saha and Dutta, 2013).

To control hibernating insects pests of rice field cutting of border edges of crop field before transplanting. Hibernated pests are killed and thus reduce the pest population at later stage of the crop (Saha and Dutta, 2013).

In Assam, farmers used to place Drum stick (Moringa oleifera Lam.) twigs and barks in the rice field to check infestation of stem borers. As because drum stick twigs and barks act as insect repellent (Majumder et al., 2013).

Control of stored grain pests: There is a common practice of storing food grains like rice, pulses in Madhya Pradesh by using neem leaves to prevent storage pest damage (Shakrawar et al., 2018).

Leaves and twigs of Bihlongoni (Poygonum spp) or Bihdhekia (Sphaerostiphonos unitus) are kept in the bins during storage of grains to repel several rice pests in North Bank plain zone of Assam, (Majumder et al., 2013). Highly pubescent leaves of wild fern are very pungent and cause irritations on the animal skin. Fern has insecticidal activity (Bhuyan, 2003).

Seed mixed with Acorus calamus (bos) powder in the ratio of $10 \mathrm{~kg}$ : $1 \mathrm{~kg}$, would help in preserving the seed free from stored pests for long time (Shakrawar et al., 2018).

Placing long hair of women in the crown portion of coconut tree to control rhinoceros beetle (Oryctes rhinoceros). The beetle engulfed with long hair due to which they cannot move (Deka et al., 2006).

Placing of curry leaves (Murraya koenigii Spreng.) in grain storage to control stored grain pests. Odour of curry leaves repel many stored grain pests (Deka et al., 2006). 
Application of lime to the field before planting of rhizomes of ginger to avoid pest attack (Rajput et al., 2018).

Placing of 6-12 inch thick layer of rice husk on the top of grains stored in Duli (Bamboo storage bin) to reduce infestation of rice moth (Kalita and Hazarika, 2019)

Introduction of red tree ant, Oecophylla smaragdina into the rice godown to predate upon the stored insect pest in rice (Kalita and Hazarika, 2019).

Covering of jute bags containing seed with drt wheat straw to reduce entry of stored insect pests in wheat (Kalita and Hazarika, 2019).

Deposit of a layer of neem, A. indica / posotia leaves at the bottom of the stored potato to act as repellent and toxicant( (Kalita and Hazarika, 2019).

Fixing of jackfruit pieces in bamboo sticks in rice fields to attract insects due to smell of jackfruit which later dies (Shyam et al., 2019).

Placing sticks of banana leaves in rice field to attract Gundhi bug during milky stage of the crop (Shyam et al., 2019).

Spraying of $0.2 \%$ neem based extract prepared by mixing $250 \mathrm{~g}$ neem leaves, $250 \mathrm{~g}$ cowdung in 10 lit of water in tea bushes to control Red spider mites (Saikia et al., 2007).

\section{ITKs in crop disease management}

Tribal farmers of Chhindwara district of Madhya Pradesh use fermented solution of $5 \mathrm{~kg}$ of cow dung, 5 litre of cow urine, 150 gm lime +100 litre of water to control khaira disease, bacterial and viral diseases in paddy (Shakrawar et al., 2018).

Cowdung is mixed with water thoroughly and kept for 3-4 hours till the course materials settle down. The solution on top is filtered and sprayed on paddy leaf for control of bacterial blight. Bactericidal action of cowdung helps reduce the population of the bacteria (Xanthomonas sp.) (Shakrawar et al., 2018)

Some farmers of tribal areas of Madhya Pradesh used to apply fresh cow dung near the collar region of chilli plant to control fungal disease, viz. damping off and dieback (Shakrawar et al., 2018).

For management of brown spot disease of rice, farmers used to prepare solution from $2 \mathrm{~kg}$ fresh leaves of papaya in 3-4 liters of water. That solution is need to be kept overnight. After that solution is filtered by using a cloth. Then, that is diluted in 50-60 liters of water. In that solution $250 \mathrm{ml}$ of soap solution can be added as a sticker or surfactant (Roy et al., 2015 and Shakrawar et al., 2018).

Brown spot of rice can be controlled by spraying ash prepared by mixing ash with water. The spraying should be done at panicle initiation stage of rice. The reason behind this ITK is that ash contains hydrocarbon and/or sulphur which may prevent the spreading of infection. Moreover, ash is alkaline in nature so it reduces the fungal infection (Saha and Dutta, 2013).

To prevent blight and fruit rot disease of brinjal and tomato, farmers used to spread rice straw at the base of the plant especially during fruiting stage. Due to straw the branches of the plants and fruits do not come in contact with the soil and thus fruit rot and blight disease is prevented (Saha and Dutta, 2013).

Cultivation of marigold followed by solanaceous vegetable crop is effective to control bacterial diseases (Roy et al., 2015).

Some farmers used to apply fresh cow dung near the collar region of chilli plant to control fungal disease, viz., damping off and die back (Roy et al., 2015).

In Manipur, seedlings of vegetable such as 
tomato, chilli etc. are raised in artificial tray made up of half split bamboo at $3-4 \mathrm{ft}$ height by many farmers. This is mainly done to control damping off of seedlings. This practice helps in production of disease free seedlings (Gogoi, 2010).

In case of bunchy top disease in chillies, dusting of ash, spray of liquid waste of tanned leather is used in tribal areas of West Bengal (Roy et al., 2015).

\section{ITKs in pest and disease management of horticultural crops}

Ash is mixed thoroughly @ 20 g (10 tsp) per $\mathrm{kg}$ seed for the storage of okra seeds to manage storage pests of okra (Gohain et al., 2019). Ash kills insects by desiccation or by filling the inter granular spaces restricting insect movement and insect emergence (Chandola et al., 2011).

Fish washed water is applied at the base of lemon tree to control Cirtus trunk borer (Gohain et al., 2019). The smell of the fish water act as repellent for the insect (Deka et al., 2006).

Kerosene is applied to the trunk of the mandarin tree to control Trunk borer and stem borer in fruit crops (Gohain et al., 2019). The holes made by the trunk borer and stem borer are plugged using mud or cow dung after applying kerosene which kills larvae of insects (Barooah and Pathak, 2009).

Ripe banana or crushed sugarcane stock is buried under the ground near the main field of potato plantation for management of Red ant and mites (Dutta and Chakravorty, 2009 and Gohain et al., 2019). It is used as insect trap. The sweet flavour and taste of ripe banana and sugarcane attract the red ants and mites from the main field and they are smashed manually.

Application of smoke in the morning and evening time in cucurbitaceous plants to control Fruit sucking moth (Gohain et al., 2019). Deter away the fruit borer and other pests (Deka et al., 2006).

Wood ash is applied at the base leaves of crops like brinjal, okra, mustard, spinach etc. for the control of Aphids, leaf minor, thrips and beetles (Saha and Dutta, 2013, Gohain et al., 2019). The ash sticking to the leaf changes the $\mathrm{pH}$ of the plant surface; this in turn makes it inhospitable for insects.

In case of coconut and arecanut plantation, rice husk, twigs etc. are burnt in the pit before planting to control Termite (Gohain et al., 2019). Burning kills the insect and the left over ashes repel termites.

Tying of unused recordable tapes or plastic ribbon in a criss cross manner in vegetable garden to control birds attack (Gohain et $a l ., 2019)$. Whistling sound appears due to wind and the light reflection due to sun on the taps deters away the birds.

Placing of nest of weaver ant (Oecophyllas maragadina) on the citrus plant to manage Trunk borer and defoliators (Gohain et al., 2019). The rationale behind the technology is that hunting and killing the insect which is potentially harmful for the citrus plant (Barzman et al., 1996).

Use of iron wire for piercing into the plant to kill grub in infested arecanut trees to control Red palm weevil (Gohain et al., 2019). It kills the grubs mechanically (Umdor, 2004).

Spraying of boiled tobacco leaf extract on vegetables to control Lepidopteran pests (Saha and Dutta, 2013, Gohain et al., 2019). Nicotin an alkaloid) and alkalinity of tobacco leaf extract prevents the attack of pests (Fireke et al., 2013).

Smoke is generated at the orchard of fruit trees like mango and jackfruit at the time of flowering to manage Fruit moths (Gohain et al., 2019). Smoke repels the fruit moth and protects fruits from laying eggs. 
Placing of dead frog at the base of coconut tree to control Rhinoceros beetle (Gohain et al., 2019). Foul smell attracts the rhinoceros beetles and the bugs are destroyed manually.

Lime powder is applied at the base with a distance of 6 inch from the root zone area in plants like lemon, orange, chilli etc. to control snails, ants, mites etc. (Gohain et al., 2019). The corrosive base properties of lime repel the pests.

Painting the trunk of mandarin plants by lime to control Gummosis diasease and bark eating caterpillar, trunk borer etc. (Gohain et al., 2019). The corrosive nature of lime act as repellent for insect pests.

Use of table salt at the base of the plants like banana to control snails (Gohain et al., 2019). Salt being desiccant in nature can kill the snails.

Application of turmeric powder in the seed bed of vegetable crops like tomato, cabbage, cauliflower etc. to control Red ants (Gohain et al., 2019). The odour of turmeric acts as repellent for the ants and has fungicidal properties.

The seeds of chilli, tomato, brinjal etc. are rubbed with a mixture of kerosene and ash before sowing to control the attack of red ants (Gohain et al., 2019). The smell and taste of kerosene and ash make the seeds inconsumable to the red ant.

Mixed cropping of chilli, coriander and garlic to manage wilt diseases of chilli (Gohain et al., 2019). The smell of coriander and garlic works as repellent for the vector insects, i.e., aphids.

Application of salt solution at seedling stage of vegetable crops to control red ant. Salt characteristics repel the red ants from the treated area (Saha and Dutta, 2013).

Regular smoking by rice straw and chilli powder at fruiting stage to control fruit fly of vegetable crops. Smokes with unbearable odour prevent the attack of fruit fly (Saha and Dutta, 2013).
To prevent field crickets of vegetable crops at seeding stage smoking is done by burning dried chilli in front of the holes of cricket pests. Due to the effect of smoke crickets come out from the holes and then it can easily be killed (Saha and Dutta, 2013).

Spreading of ash dust in vegetables like pumpkin, gourd, muskmelon and water melons is done to repel insect pests like red pumpkin beetle (Berjesh and Kunar, 2011).

Farmers of West Tripura district control papaya mealy bug (Paracoccus marginatus) by thorough dusting of fresh ash during the morning hours (Gogoi et al., 2010).

In order to prevent fruit rotting in brinjal plants, a solution is made of 1 litre of water and eight crushed leaves of Aloe vera and sprayed on the crop (Rajput et al., 2018).

\section{Some of the scientifically validated ITKs}

Farmers of West Bengal used to prepare indigenous pesticide by using cow urine and jaggery/gurr. Firsty, the fresh urine is collected in a container. Then $1 / 2 \mathrm{~kg}$ jaggery, 1 litre of cow urine and 2 litres of water is mixed together. The mixture is then stored inside an air tight plastic container and is kept for about 6 months. After 6 months of decomposition, it is diluted by adding water (1 litre concentrated pesticide is mixed with 7 litres of water) and filtered using a clean cloth and then the mixture can be sprayed on field crops.

It kills insect pests of field crops. The scientific rationale behind this ITK is that the toxicity of the mixture kills the insect pests that come in contact with it (Pradhan et al., 2017).

Crush $5 \mathrm{~kg}$ neem leaves in water, add 5 lit of cow urine and $2 \mathrm{~kg}$ of cow dung and then ferment for $24 \mathrm{hrs}$ with intermittent 
stirring. Then filter the extract and dilute it in 100 lit of water for spraying over one acre. This extract is useful against sucking pests and mealy bugs. It can be used in vegetable crops (NCOF, Gaziabad, 2011-12).

Aloe (Aloe barbadensis; Fam: Aloeaceae) and vitex (Vitex negundo; Fam: Verbenaceae) extract: Soak vitex leaves $(5 \mathrm{~kg})$ in 10 liters of water. Then boil that mixture for 30 minutes. Cool the extract and then strain by using a cloth. Remove the outer part of the aloe leaves $(2 \mathrm{~kg})$ and grind in water to get the extract. Mix these two extracts and dilute in 50-60 liters of water to cover 0.4 ha area. Add $50-60 \mathrm{ml}$ soap in the mixture and spray early in the morning or late in the afternoon. This Aloe vitex extract is reported to control armyworm, hairy caterpillar, rice leaf folder, rice stem borer, semi-looper, bacterial and fungal diseases (Bissdorf, 2008).

For control of sucking pests, pod/fruit borers a mixture of leaf extracts of neem, custard apple, papaya, pomegranate and guava can be used. For that crush $3 \mathrm{~kg}$ of neem leaves in 10 litre cow urine, crush $2 \mathrm{~kg}$ custard apple leaves, $2 \mathrm{~kg}$ papaya leaves, $2 \mathrm{~kg}$ pomegranate leaves and 2 $\mathrm{kg}$ guava leaves in water. Mix the two and boil till it becomes half. Keep for 24 hours, then filter squeeze the extract. This can be stored in bottles for 6 months. Dilute 2-2.5 litre against sucking pests, pod/fruit borers (NCOF, Gaziabad, 2011-12).

In conclusion the present day context, where everybody is concerned with affects of chemicals towards health and environment, documentation and scientific validation of the ITKs can play a vital role in development of Agricultural Science. The major constraints on wider adaptability of ITKs are, lack of knowledge of farmers and farm women regarding processing of herbs and other locally available natural resources for preparation of indigenous pesticides, appropriate method of preparation and dose of application, lack of documentation and validation of ITKs etc. Adoption of ITK based crop protection measures as an alternative to pesticides might help in restoring the biodiversity of natural enemies. Hence, this type of documentation will surely serve as a ready reference for the agricultural scientists for further study on validation, effectiveness and dissemination of indigenous technologies and can lead to development of effective modules, more particularly the integrated pest and disease management modules for major agricultural crops. It is the need of the time to integrate the scientifically validated ITKs with the recommended package and practices of agricultural system for wider acceptability.

\section{Acknowledgement}

We acknowledged the help, guidance and continuous support received from Dr. P. K. Pathak, Director of Extension Education, Assam Agricultural University, Joraht-13, Assam and Dr. A. K. Tripathi, Director ATARI, Zone VI, Guwahati, Assam.

\section{References}

Barooah, M., and Pathak, A., 2009. Indigenous knowledge and practices of Thengal Kachari women in sustainable management of bari system of farming. Indian Journal of Traditional Knowledge, 8(1), 25-40.

Barzman, MS., Mills, J., and Thu, Cue, N., 1996. Traditional knowledge and rational for weaver ant husbandry in the Mekong delta of Vietnam. Agriculture and human value, 13(4), 2-9.

Berkes, F., Colding, J., and Folke, C., 2000. Rediscovery of traditional ecological 
knowledge as adaptive management, Ecological Application. 10(5), 12511262.

Bhuyan, M., 2003. Studies on some potential insect control agents from plants of North East India, $\mathrm{Ph} \mathrm{D}$ Thesis, Dibrugarh University, Assam.

Bissdorf, JK., 2008. How to Grow Crops without Endosulfan - Field Guide to Non-chemical Pest Management, (Ed. Carina Webber), Pesticide Action Network (PAN), Hamburg, Germany, pp 71.

Boruah, S., 2014. Bioformulation of Metarhizium anisopliae for the management of cow pea mosaic disease. MSc. Thesis. Assam Agriculltural University. p. 99.

Chandola, M., Rathore, S., and Kumar, B., 2011. Indigenous pest management practices prevalent among hill farmers of Uttarakhand, Indian Journal of Traditional Knowledge. 10(2), 311-315.

Deka, MK., Bhuyan, M., and Hazarika, LK., 2006. Traditional pest management practices of Assam, Indian Journal of Traditional Knowledge. 5(1), 75-78.

Dutta, P., Kaman, P., Kaushik, H., and Boruah, S., 2015. Biotechnological and nanotechnological approaches for better plant health management. Trends in Biosciences. 8(22): 6051-6065.

Firake, DM., Ytan, D., Thubru, DP., Behere, G., and Thakur, NS., 2013. Traditional pest management practices and beliefs of different ethnic tribes of Meghalaya, North Eastern Himalaya, Indian Journal of Hill Farming, 26(1), 58-61.

Gogoi, R., and Majumder, D., 2001. Traditional agricultural pest management practices followed in Assam, Asian Agri-History, 5(3), 253257.

Gohain, S., Neog, M., and Bhattacharyya, HC., 2019. Innovative traditional pest management practices in horticultural crops, Asian Agri-History. 23(1), 6164.

Grenier, L., 1998. Working with indigenous knowledge: a guide for researchers. Ottawa, Ontario, Canada: International Development Research Center. Retrieved December, 2017 from https://www.idrc.ca/en/book/ workingindigenous-knowledge-guideresearchers.

Hazarika, LK., Kalita, S., Nath, RK., Malakar, D., Bora, LC., and Bora, BC., 2009. Traditional rice pest management practices in Assam. In: Indigenous knowledge systems and common people's right (Ed. D. Das Gupta). pp.119-140.

Kalita, B., Dutta, A., Bhagwati, SK., and Sharma, A., 2010. Indigenous technical knowledge for fish harvesting in Karbi - Anglong district of Assam. Indian Journal of Traditional Knowledge. 9(2), $252-255$.

Kalita S and Hazarika LK, Indigenous technical knowledge (ITK) on storage pest management and ritual-based farming practices in Assam, Asian AgriHistory, 23(1) (2019) 1-14.

Majumder, D., Deka, SN., Pujari, D., and Das, PK., 2013. Traditional knowledge adopted by the farmers for management of rice pests in North bank plain zone of Assam, Indian Journal of Traditional Knowledge. 12(4), 725-729.

Patel, LC., 2013. Innovative trap for rat control with bamboo materials. Frontier farming, 1(3), 33.

Patnaik, HP., 2017. Indigenous technical knowledge (ITK) in pest management for sustainable agriculture. In: OUAT Souvenir. http://www.orienvis.nic.in/indexx.aspx? langid $=1 \&$ slid $=1076 \& \mathrm{mid}=2 \&$ sublinkid $=345$

Pradhan, K., Yolmo, Z., Saha, A., and Prasad, CV., 2017. Identification and 
documentation of indigenous technological knowledge (s) regarding pest control methods in agriculture, International Journal of agriculture sciences, 9(38), 4580-4584.

Rajput, AS., Jariyal, M., and Singla, A., 2018. Transition from conventional farming to organic farming. In: Transition from conventional farming to organic farming. Regional Centre of Organic Farming, Bhubaneswar, Odisha (Eds. Dr. Ajay Singh Rajput et al.), p.1-8.

Roy, S., Rathor, A., Sarkar, S., and Roy, K., 2015. Use of ITK in plant protection, Popular Kheti. 3(2), 75-78.

Saha, B., and Dutta, P., 2013. Indigenous methods of crop protection: An Indian Scenario. In: Current concepts in Crop Protection (Ed. Susanta Banik). Stadium press India Pvt Ltd, pp: 411-429.

Saikia, GK., Bhuyan, RP., Deka, A., Baruah, S., Neog, RC., and Dutta, MRS., 2007. Traditional practices adopted by the small growers of Assam for tea pest management. In: Nene, SL Choudhury,
Saxena, RC, Nene, YL., and Simlot, MM.(eds.), Traditional Agricultural Practices with Potential for Growing Plantation Crops: Proceedings of the National Conference held from 22-24 February, Assam Agricultural University, Jorhat, Assam.

Shakrawar, M., Naberia, S., and Pande, AK., 2018. Indigenous technical knowledge for pest, disease and weed management in agriculture, International Journal of chemical Studies. 6(4), 497-498.

Shyam, P., Buragohain, R., Deka, N., and Hazarika, JP., 2019. An impression of Indigenous Technical Knowledge (ITK) for rice used by Tai Khamyang Community of Assam, India. Asian Agri History. 23(3), 205-212.

Umdor, M., 2004. Indigenous practices on protection of Areca catechu Linn. Seedlings: A case study in Meghalaya. Indian Journal of Traditional Knowledge. 3, 253-255.

\section{How to cite this article:}

Sarodee Boruah, Sanjoy Borthakur and Neog, M. 2020. Indigenous Technological Knowledge in Pest and Disease Management of Agricultural Crops - A Review Int.J.Curr.Microbiol.App.Sci. 9(09): 2867-2876. doi: https://doi.org/10.20546/ijcmas.2020.909.354 